\title{
A Study on Ganre-Based Approach in Teaching Speaking to Indonesian EFL Learners
}

\author{
Rangga Mega Putra \\ Universitas Sarjanawiyata Tamansiswa Yogyakarta, Indonesia \\ Email: megarangga21@gmail.com
}

\begin{abstract}
The implementation of genre-based approach in EFL teaching has been increasingly attracting many EFL teachers' attention. This study aimed at investigating the implementation of Ganre-Based Approach in teaching and learning process of speaking skill at SMPN 1 Gamping Yogyakarta. This study was descriptive qualitative. The techniques of collecting the data were observation, interviews and documentation. The data was analyzed by referring to theory of the stages of genre-based approach developed by Hammond et al., (1992). The total of the sample of this study was 28 students in the seventh grade of SMPN 1 Gamping Yogyakarta. The findings showed that the English teacher still had some weakness in implementing genre-based approach. Moreover, the students still had many difficulties in generic structure and social function of the text.
\end{abstract}

Keywords: EFL learners, Ganre Based Approach, Speaking skill.

\section{INTRODUCTION}

Speaking is, with no doubt, of paramount importance of English as foreign language (EFL) learning. Richards \& Renandya (2002) stated that the majority of the world's language learners study English in order to enhance proficiency in speaking. Furthermore, the students perceived of the potential of speaking skill in supporting their future carrier (Dincer, 2017; Pakkala, 2017). Nevertheless, despite speaking skill' significance, the teaching of this skill repeatedly encounters many barriers and challenges such as native language, age, exposure, innate phonetic ability, motivation (Nuraini, 2016), anxiety, learners' autonomy (Kara \& Ayaz, 2017), inhibition, low participation (Hosni, 2004) and the limited time allocation (Nazara, 2011).

In Indonesian context, therefore, a wide variety of classroom activities and teaching materials have been made, selected, and implemented to foster speaking proficiency of Indonesian EFL learners (Widiawati \& Cahyono, 2006). However, some linguistic and non-linguistic factors need to be paid big attention in organizing speaking classes. In term of strategy, Prabawa (2017) stated that Indonesian students tend to mostly utilize compensation strategy in improving their speaking ability.

One of the approaches that may be implemented to improve EFL learners' speaking skill is genre-based approach has been extensively employed in different curriculum fields to enhance learners' meaning-making potential. By means of the text as the major unit of communication and pedagogy, this approach envisages language learning and use as a social, textual, and goaloriented process. Genre-based approach is one of approaches which are being growingly implemented in ESL/EFL teaching. As a 
result, it is considered as one of the great trends in language teaching today (Rodgers, 2001). In line with this, Hyland (2003) argues that genre approaches have a significant influence toward the way a language is used on literacy education around the globe.

When it comes to the contribution of genre-based approach in EFL instruction, there have been a great number of previous studies focusing on the use of GBA in teaching the basic linguistic skills, particularly in teaching writing (Nagao, 2018; Correa \& Echeverri, 2017; Burgos, 2017; Dirgeyasa, 2016; (Sabouri, et.al., 2014), reading (Adelnia \& Salehi, 2016; Sadeghi, et.al., 2013), listening (Cahyono, 2017). Similar to other basic skills, some researchers such as Rifpriyandi \& Sudartini (2017), Khatibi (2014), Hapsari (2017), and Rivera (2014) have also shown that the implementation of genre-based approach may positively affect the EFL students' speaking and communicating skill.

The wide variety of studies on genrebased approach in the teaching of speaking indicates that this approach is scientifically proven effective to contribute to the EFL learners' speaking ability. Nevertheless, the studies specialized on how EFL teacher implemented the genre-based approach to teach speaking are still considered rare. The present study seems similar to prior studied since it intended to strengthen the findings of previously conducted researches; however, it actually differs from them due to its type of research which was a qualitative case study that was focused on the implementation of genre-based approach and its focus on the teaching of speaking to the first-year students of middle school.

\section{EFL Speaking Skill}

According to O'Grady \& Dobrovosky (2000), in psycholinguistic, speaking is a productive language skill. Thornbury \& Slade (2006) maintains that speaking is very omnipresent in everyday language usage. Meaning to say, speaking is so entangled with daily interactions that it is complicated to identify.

To know how an EFL learner is indicated to have a proper speaking skill, Harris (1974) classifies the components of speaking skill into five components, namely comprehension, grammar, vocabulary, pronunciation, and fluency.

a. Comprehension

For oral communication, comprehension certainly requires a subject to respond to the speech as well as to initiate it.

\section{b. Grammar}

According to Harmer (2007), the grammar of a language is the depiction of the ways in which words can transform their forms and can be mixed into sentences in a language. If grammar rules are too imprecisely violated, communication may run improperly, although, producing a 'good' grammar rule is tremendously intricate. Grammar is one pf vital aspects of speaking because an utterance may have dissimilar meaning if the speaker uses inaccurate grammar.

\section{c. Vocabulary}

One cannot communicate effectively or express their ideas both oral and written form if they do not have sufficient vocabulary. Without grammar, very little can be conveyed, without vocabulary nothing can be conveyed.

\section{d. Pronunciation}

Pronunciation is an indispensable feature of learning to speak a foreign language. If a learner does not pronounce a word appropriately, it can be very daunting to get the point he or she delivers. On the other 
hand, if students make grammatical mistakes e.g. in a verb tense, the listener still has an idea of what is being said. Hence, it can be seen that good pronunciation is vital if a student is to be understood.

\section{e. Fluency}

According to Brown (2001), fluency can be defined as the capability to speak smoothly and precisely. Fluency in speaking is the aim of the majority of language learners. Signs of fluency comprise a practically fast speed of speaking and only a small number of pauses and "ums" or "ers". These signs point out that the speaker does not spend a lot of time searching for the language items needed to articulate the message.

\section{f. Content}

In speaking, the speaker and the listener must have a good mutual understanding in order that the conversation, without doubt, requires a subject to answer to speech as well as to duplicate it.

\section{The Teaching of Speaking}

The goal of the teaching of speaking, unquestionably, is to boost the students' oral production. Thus, language pedagogical activities in the classroom should endeavor at taking full advantage of individual language use.

According to Nunan (1998), teaching speaking is a very important part of second language learning. The ability to communicate in a second language clearly and efficiently contributes to the success of the learner at school and success later in every phase of life. Therefore, it is essential that language teacher pay great attention to the teaching of speaking. The teachers are expected to offer a rich environment where meaningful communication occurs, rather than merely leading the students to pure memorization. To teach speaking, four aspects must unavoidably be considered (Brown, in Madkur, 2018). They are fluency, accuracy, pronunciation, and vocabulary. Meanwhile, Nunan (1992), in this case, formulates what is meant by the teaching of speaking:

1. Producing the English speech sounds and sound patterns

2. Using word and sentence stress, intonation patterns and the rhythm of the second language.

3. Selecting suitable words and sentences based on the proper social setting, audience, situation and subject matter.

4. Organizing the learners' thoughts in a meaningful and logical cycle.

5. Using language as a tool of expressing values and judgments.

6. Using the language fast and assertively with few unnatural stops, which is called as fluency.

\section{Ganre Based Approach (GBA)}

At junior high school, the English teaching and learning process is targeted to enable students to gain the ability to communicate in daily life context. As language is a mean of communication, the students have to be accustomed to speak English orally. Their communicative competence has to be developed through tasks and activities which are carried out during the teaching and learning process. Considering the fact that the students of junior high school are still young learners, the teacher has to organize the lesson based on their needs, interest, and characteristics as well. They need enjoyable activities, which involves body movement, pictures, real objects, during the teaching and learning process. Accoording to Hyland (2003), ganre-based approach can be understood when one examines the two cycles 
and four stages. The two cycles and four stages recommended are represented in the following diagram:

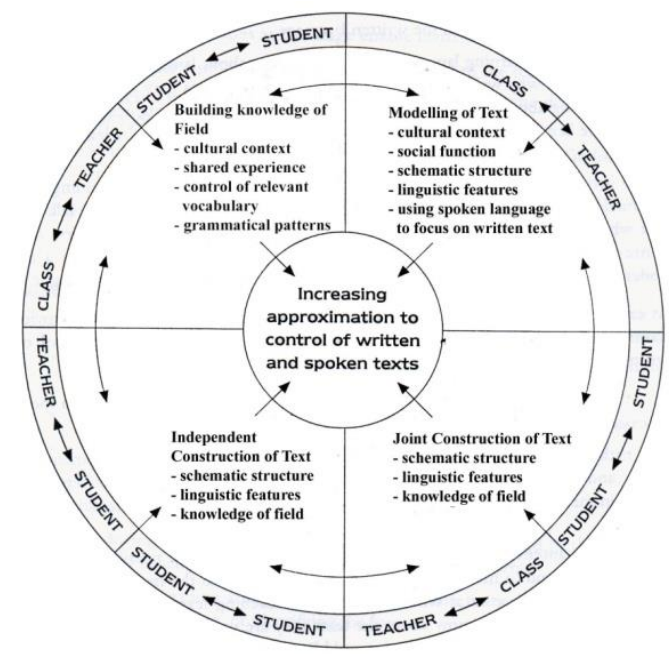

Diagram 1: Cycles and Stages of Learning (Hammond et al., 1992)

Then, to implement genre-based approach, the following steps should be carried out:

1. In planning the lessons in foreign language education context, the teachers need to go around the cycle twice. In the initial cycle, they begin from the first stage called Building Knowledge of the Field (BKOF) where teachers and students construct cultural context, share experiences, discuss vocabulary, grammatical patterns and so forth. All of these are geared around the kinds of spoken texts and topics they are going to deal with at the second stage.

2. The next stage is Modeling of Text (MOT) where students listen to statements of short functional texts, conversations, and monologues that are geared around a certain communicative purpose. For example, if the students are expected to produce procedural texts, then, the short functional texts, conversations, and the monologues are developed with one main communicative purpose, that is, giving instruction or direction. In short, at the second stage, the students listen and respond to a range of texts with related communicative purposes.

3. After listening, students come into the stage three called Joint Construction of Text (JCOT). At this stage, they try to develop spoken texts with their peers and guided by the teachers. They can generate any kinds of announcements, conversations on showing how to do things, monologues on how to make something and so on. They need to display their speaking capability and to show self-confidence to speak.

4. After having the experience of collaboration with friends, they enter the fourth stage called Independent Construction of Text (ICOT). At this stage, the students are encouraged to be able to speak impulsively or to carry our monologues aimed at giving directions or showing ways to do things such as how to make a kite, how to make a paper cap, and so forth. Hence, the first cycle integrates the advance of speaking and listening skills.

\section{METHOD}

This research was qualitative with a case study approach, in which the researcher studied the particularity and complexity of a single case, coming to understand its activity within main conditions (Stake, 1995). The purpose of a case study is to present a more thorough analysis of a circumstance or "case" which will disclose attention-grabbing information to the readers. Besides that, it is an in-depth investigation of one participant. This participant is called a "case" and can be one person, one animal, or one group.

This research was conducted to the seventh gradersof a junior high school. The 
school was SMP Negeril Gamping, located in Sleman Yogyakarta, Indonesia.

To collect the data, the researchers did observation, interviews and documentation. The instruments were the observation guide developed from the Hammond's et.al. theory. Also, since this is a qualitative research, the researcher herself was an instrument. As an instrument of the research, the researcher determined the focus of research, chose the object of the research, determined the data source, conducted the data collection, valued the quality of the data, and then made a conclusion based on the finding of the research.

\section{FINDINGS AND DISCUSSION}

To comprehensively see the implementation of genre-based approach in the teaching of speaking at SMP Negeri 1 Gamping, Sleman, the researcher employed the observation guide she had developed from the theory of Cycles and Stages of Learning (Hammond et al., 1992). Therefore, the findings are presented as follows.

Teaching activities in the stage of Building Knowledge of the Field (BKOF)

Table 1 Activities in BKOF

\begin{tabular}{|c|c|c|}
\hline No & $\begin{array}{c}\text { According to } \\
\text { Hammond et al } \\
(1992: 19)\end{array}$ & $\begin{array}{c}\text { Teacher's } \\
\text { observation }\end{array}$ \\
\hline 1. & $\begin{array}{l}\text { Learners are encouraged } \\
\text { to discover cultural } \\
\text { similarities and } \\
\text { differences related to the } \\
\text { topic including: } \\
\text { processes undergone in } \\
\text { reaching goals and } \\
\text { shared experiences }\end{array}$ & $\begin{array}{l}\text { The teacher started } \\
\text { the class by giving } \\
\text { the questions } \\
\text { related to the topic }\end{array}$ \\
\hline 2. & $\begin{array}{l}\text { Learners are expected to } \\
\text { practice grammatical } \\
\text { patterns relevant to the } \\
\text { topic or text type. }\end{array}$ & $\begin{array}{l}\text { The teachers did } \\
\text { not practice } \\
\text { grammatical } \\
\text { patterns. }\end{array}$ \\
\hline 3. & $\begin{array}{l}\text { Learners are stimulated } \\
\text { to build up and enrich } \\
\text { vocabulary relevant to } \\
\text { the topic or text type }\end{array}$ & $\begin{array}{l}\text { The teacher taught } \\
\text { the vocabulary. }\end{array}$ \\
\hline
\end{tabular}

From the classroom observation and interview, the teacher did not apply some activities in BKOF. The teacher tried to implement BKOF stage but the current implementation was not appropriate. It can be seen in the interview that the teacher explained the activity in BKOF was warm up. The teacher did not explore cultural similarities to support the language teaching (Albantani \& Madkur, 2018) and differences of text and the teacher did not teach grammatical pattern. In fact, grammatical aspect is definitely important in learning a language (Alqahtani, 2016) especially how to speak. In conclusion, the teacher only implemented one aspect, which was teaching vocabulary.

\section{Teaching activities in the stage of Modeling of Text (MOT)}

At this stage, the teaching activities could be seen as follows:

Table 2 Activities in MOT

\begin{tabular}{|c|c|c|}
\hline No & $\begin{array}{c}\text { According to } \\
\text { Hammond et al } \\
(1992: 20)\end{array}$ & $\begin{array}{l}\text { According to teacher } \\
\text { in the Observation }\end{array}$ \\
\hline 1. & $\begin{array}{l}\text { Learners are asked } \\
\text { to read the model } \\
\text { text with the } \\
\text { teacher, with other } \\
\text { students are alone }\end{array}$ & $\begin{array}{l}\text { The teacher told the } \\
\text { genre of the text then } \\
\text { asked them to read } \\
\text { together }\end{array}$ \\
\hline 2. & $\begin{array}{l}\text { Learners should be } \\
\text { able to develop an } \\
\text { understanding of } \\
\text { the social function } \\
\text { and purpose of the } \\
\text { text }\end{array}$ & $\begin{array}{l}\text { The teacher asked the } \\
\text { function of descriptive } \\
\text { text. }\end{array}$ \\
\hline 3. & $\begin{array}{l}\text { Learners to develop } \\
\text { and understanding } \\
\text { of the overall } \\
\text { organization and } \\
\text { development of the } \\
\text { text. }\end{array}$ & $\begin{array}{l}\text { The teacher explained } \\
\text { each generic structure } \\
\text { and analyze together } \\
\text { with the students. }\end{array}$ \\
\hline
\end{tabular}

In MOT, the teacher introduced a topic or text type to the students by using PowerPoint. According to Hammond et al. (1992), there are three aspects in the MOT 
stage, such as learners to read the model text with the teacher with other students are alone, learners to develop an understanding of the social function and purpose of the text. But, the teacher had difficulty for learners to develop and understanding of overall organization and development of the text.

Teaching activities in the stage of Joint Construction of Text (JCOT).

At this stage, only two activities were observed. As seen in table below.

\section{Table 3. Activities in JCOT}

\begin{tabular}{|c|c|c|}
\hline No & $\begin{array}{c}\text { According to } \\
\text { Hammond et al } \\
(1992: 23)\end{array}$ & $\begin{array}{l}\text { According to } \\
\text { Teacher in the } \\
\text { Observation }\end{array}$ \\
\hline 1. & $\begin{array}{l}\text { Learner should } \\
\text { explore further the } \\
\text { purpose of the genre } \\
\text { and its relation } \\
\text { between the topics of } \\
\text { field }\end{array}$ & $\begin{array}{l}\text { The teacher asked to } \\
\text { make a group to } \\
\text { discuss about } \\
\text { descriptive text }\end{array}$ \\
\hline 2. & $\begin{array}{l}\text { Learners are asked to } \\
\text { contribute knowledge } \\
\text { of the field in the } \\
\text { shared construction of } \\
\text { the text }\end{array}$ & $\begin{array}{l}\text { Teacher told the } \\
\text { students to present } \\
\text { the result task of the } \\
\text { group }\end{array}$ \\
\hline
\end{tabular}

The teacher tried to apply Joint Construction of the Text by having group discussion. The teacher and students constructed the text. Teacher divided the students into some groups. Then, the teacher gave task to each group and asked students to discuss it. The task was to compose descriptive text about how to describe something and the students were asked to identify the generic structure in the their own text. The emphasis of this stage was on how the teacher provided guidance and support in order to convert and reshape the language from the spoken to the written mode. In the speaking learning process, as stated by Pae, (2017), the teacher's guidance may help increase the students' confidence to speak.
Teaching activities in the stage of
Independent Construction of Text (ICOT).

At this last stage, the classroom activities were observed as follows

Table 4. Activities in ICOT

\begin{tabular}{|c|c|c|}
\hline No & $\begin{array}{l}\text { According to } \\
\text { Hammond et al } \\
(1992: 19)\end{array}$ & $\begin{array}{c}\text { Teacher's } \\
\text { Observation }\end{array}$ \\
\hline 1. & $\begin{array}{l}\text { Learners incorporate } \\
\text { knowledge of } \\
\text { schematic structure } \\
\text { and grammatical } \\
\text { patterns into their own } \\
\text { writing }\end{array}$ & $\begin{array}{l}\text { The teacher gave } \\
\text { his students } \\
\text { homework } \\
\text { individually }\end{array}$ \\
\hline 2. & $\begin{array}{l}\text { Learners to produce } \\
\text { written text that } \\
\text { approximate control of } \\
\text { the genre }\end{array}$ & $\begin{array}{l}\text { The teacher asked } \\
\text { students to write } \\
\text { their own } \\
\text { descriptive text }\end{array}$ \\
\hline
\end{tabular}

In ICOT, according to Hammond et al. (1992), the EFL learners should be able to incorporate knowledge of schematic structure and grammatical patterns into their own writing. In doing so, the teacher asked students to write the text by themselves. However, because time was over, the teacher asked to continue it in the next meeting.

\section{CONCLUSION}

This research support the previous studies disclosing the positive effect of genre-based approach in teaching speaking. However, it unveils that the implementation of genrebased approach in the teaching of speaking at SMP N 1 Gamping Yogyakarta was still in need of betterment. The difficulties were still faced by the teacher in the implementation genre-based approach in the four stages. In BKOF, the teacher didn't understand to apply activities. Then, the teacher found it difficult to make the students able to analyze of generic structure and social function of text, because students' vocabulary mastery is low so the students didn't know the content of the text. Also, the teacher had difficulties to make the 
students active in discussion. Last but not least, the teacher had difficulty in arranging the time.

This condition influenced the effectiveness of this approach in the classroom. Thus, this research conclude that the EFL teachers need to be able to identify which aspect of this approach is still incomplete so that they know how to complete it and, in turn, the instruction of speaking may run better.

\section{REFERENCES}

Adelnia, R., \& Salehi, H. (2016). Improving Iranian High School Students ' Reading Comprehension Using the Tenets of Genre Analysis. Advances in Language and Literary Studies ISSN:, 7(4), 187196.

https://doi.org/10.7575/aiac.alls.v.7n.4p. 187

Albantani, A. M., \& Madkur, A. (2018). Think Globally , Act Locally: The Strategy of Incorporating Local Wisdom in Foreign Language Teaching in Indonesia. International Journal of Applied Linguistics \& English Literature, $\quad 7(2), \quad 1-8$. https://doi.org/http://dx.doi.org/10.7575/ aiac.ijalel.v.7n.2p.1

Alqahtani, M. (2016). The importance of vocabulary in language learning and how to be taught (2016) III(3) 21-34. International Journal of Teaching and Education, $\quad$ III(3), 21034. https://doi.org/https://doi.org/10.20472/t e.2015.3.3.002

Brown, D. (2001). Teaching by Principles An Interactive Approach to Language Pedagogy (2nd editio). New York: Addison Wesley Longman.
Burgos, E. G. (2017). Use of the Genre-Based Approach to Teach Expository Essays to English Pedagogy Students. HOW, 24(2), 141-159. https://doi.org/http://dx.doi.org/10.1918 3/how.24.2.330

Cahyono, S. P. (2017). The Implementation of Genre Based Approach to Teaching Narrative Listening. Advances in Social Science, Education and Humanities Research (ASSEHR), 66(Yicemap), 284289.

Correa, D., \& Echeverri, S. (2017). Using a Systemic Functional Genre-Based Approach to Promote a Situated View of Academic Writing Among EFL Preservice Teachers. HOW, 24(1), 44-62.

Dincer, A. (2017). EFL Learners' Beliefs about Speaking English and Being a Good Speaker: A Metaphor Analysis. Universal Journal of Educational Research, 5(1), 104-112. https://doi.org/10.13189/ujer.2017.0501 13

Dirgeyasa, I. W. (2016). Genre-Based Approach: What and How to Teach and to Learn Writing. English Language Teaching, 9(9), 45. https://doi.org/10.5539/elt.v9n9p45

Hammond, J., Burns, A., Joyce, H., Brosnan, D., Gerot, L., Solomon, N., \& Hood, S. (1992). English for social purposes: A handbook for teachers of adult literacy. Sydney: National Centre for English Language Teaching and Research, Macquarie University.

Hapsari, S. T. (2017). The Implementation of 
Genre Based Approach in teaching Speaking to the Eighth Grade Students. Universitas Muhammadiyah Surakarta.

Harmer, J. (2007). The Practice of English Language Teaching. Malaysia: Pearson Education Longman.

Harris, D. (1974). Testing English as a Second Language. New York: Mc.Graw. Hill Book Company.

Hosni, S. Al. (2004). Speaking Difficulties Encountered by Young EFL Learner. International Journal on Studies in English Language and Literature (IJSELL), 2(6), 22-30.

Hyland, K. (2003). Genre-based pedagogies: A social response to process. Journal of Second Language Writing, 12(3), 17-29.

Kara, E., \& Ayaz, A. D. (2017). Challenges in EFL Speaking Classes in Turkish Context. European Journal of Language and Literature, $8(1), 66$. https://doi.org/10.26417/ejls.v8i1.p6674

Khatibi, M. B. (2014). The Effect of GenreBased Teaching on EFL Learners' Speaking Performance. IJERLT, 12(1), $38-52$.

Madkur, A. (2018). The non-English major lecturers speak English: The barriers encountered by adult learners. Journal on English as a Foreign Language, 8(1), 39-56.

https://doi.org/10.23971/jefl.v8i1.584

Nagao, A. (2018). A Genre-Based Approach to Writing Instruction in EFL Classroom Contexts. English in International Communication, 11(5), 130-147. https://doi.org/10.5539/elt.v11n5p130

Nazara, S. (2011). Students' Perception on EFL Speaking Skill Development. Joornal of English Teaching, 1(1), 2843.

Nunan, D. (1998). Language Teaching Methodology. Florence: Cengage Learning, Inc.

Nuraini, K. (2016). The Barriers of Teaching Speaking English for EFL Learners. ELLITE- Journal of English Language, Literature, and Teaching, 1(1).

O’Grady, W., \& Dobrovosky. (2000). Contemporary Linguistic Analysis: An Introduction. London: Copp Clark LTD.

Pae, T. I. (2017). Effects of the differences between native and non-native Englishspeaking teachers on students' attitudes and motivation toward learning English. Asia Pacific Journal of Education, 37(2), 163-178. https://doi.org/https://doi.org/10.1080/0 2188791.2016.1235012

Pakkala, V. (2017). "I think it is important to learn to speak English, for the future": Finnish upper secondary school students' opinions about teaching the speaking skill in English. University of Jyväskylä Department.

Prabawa, W. P. (2017). Speaking Strategies Used By Indonesian Tertiary Students. English Review: Journal of English Education, $\quad 4(2), \quad 231$. https://doi.org/10.25134/erjee.v4i2.337

Richards, J. C., \& Renandya, W. . (2002). Methodology in language teaching. 
Cambridge: Cambridge University Widiawati, U., \& Cahyono, B. Y. (2006). the Press.

Teaching of EFL Speaking in the Indonesian Context : the State of the Art.

Rifpriyandi, Q., \& Sudartini, S. (2017). Bahasa Dan Seni, 34(2), 269-292. Improving Students' Speaking Skills https://doi.org/10.17977/jip.v13i3.40 through the Genre-Based Approach in Grade X of Chemistry Analysis-A of SMK SMTI Yogyakarta. English Language Teaching Journal, 6(1), 126130.

Rivera, J. D. H. (2014). Using a genre-based approach to promote oral communication in the colombian english classroom. Colombian Applied Linguistics Journal, 14(2), 109. https://doi.org/10.14483/udistrital.jour.c alj.2012.2.a07

Rodgers, T. (2001). Language teaching methodology. Eric Digest.

Sabouri, H., Zohrabi, M., \& Vafa, A. (2014). Genre-Based Approach to Teaching Writing in EFL Context. International Journal of Applied Linguistic Studies, $3(1), 1-7$.

Sadeghi, B., Hassani, T. M., \& Hemmati, M. . (2013). The Effects of Genre-based Instruction on ESP Learners " Reading Comprehension. Theory and Practice in Language Studies, 3(6), 1009-1020. https://doi.org/10.4304/tpls.3.6.10091020

Stake, R. E. (1995). The Art of Case Study Research. Oaks, CA: Sage Publications.

Thornbury, S., \& Slade, D. (2006). Conversation: from description to pedagogy. Cambridge: Cambridge University Press. 